\title{
Aerobic endospore-forming bacteria from geothermal environments in northern Victoria Land, Antarctica, and Candlemas Island, South Sandwich archipelago, with the proposal of Bacillus fumarioli sp. nov.
}

\author{
N. A. Logan, ${ }^{1}$ L. Lebbe, ${ }^{2}$ B. Hoste, ${ }^{2}$ J. Goris, ${ }^{2}$ G. Forsyth, ${ }^{1}$ M. Heyndrickx, ${ }^{2} \dagger$ \\ B. L. Murray, ${ }^{1}$ N. Syme, ${ }^{1}$ D. D. Wynn-Williams ${ }^{3}$ and P. De Vos $^{2}$
}

Author for correspondence: N. A. Logan. Tel: +44 141331 3207. Fax: +44 1413313208. e-mail: n.a.logan@gcal.ac.uk

1 School of Biological and Biomedical Sciences, Glasgow Caledonian University, Cowcaddens Road, Glasgow G4 OBA, UK

2 Vakgroep BFM WE10V, Laboratorium voor Microbiologie, Universiteit Gent, K. L.

Ledeganckstraat 35, B-9000 Gent, Belgium

3 British Antarctic Survey, High Cross, Madingley Road, Cambridge CB3 0ET, UK

\begin{abstract}
Aerobic endospore-forming bacteria were isolated from soils taken from active fumaroles on Mount Rittmann and Mount Melbourne in northern Victoria Land, Antarctica, and from active and inactive fumaroles on Candlemas Island, South Sandwich archipelago. The Mt Rittmann and Mt Melbourne soils yielded a dominant, moderately thermophilic and acidophilic, aerobic endosporeformer growing at $\mathrm{pH} 5.5$ and $50{ }^{\circ} \mathrm{C}$, and further strains of the same organism were isolated from a cold, dead fumarole at Clinker Gulch, Candlemas Island. Amplified rDNA restriction analysis, SDS-PAGE and routine phenotypic tests show that the Candlemas Island isolates are not distinguishable from the Mt Rittmann strains, although the two sites are $5600 \mathrm{~km}$ apart, and 16S rDNA sequence comparisons and DNA relatedness data support the proposal of a new species, Bacillus fumarioli, the type strain of which is LMG 17489'.
\end{abstract}

Keywords: Bacillus, Bacillus fumarioli, Antarctica, geothermal soils, thermoacidophile

\section{INTRODUCTION}

Although Antarctica is largely an ice-bound continent that relies upon solar heating during the summer to support a sparse growth of terrestrial life, there exists a small number of sites where volcanic activity warms the soil and steam emissions from fumaroles condense to maintain relatively steady water supplies. The unique selective pressures of such sites make the organisms that live there of special biological interest (Broady, 1993). The Cenozoic period has seen constant volcanic activity in Antarctica, and steaming ground is

\footnotetext{
†Present address: Government Dairy Research Station, Brusselsesteenweg 370, B-9090 Melle, Belgium.

Abbreviations: ARDRA, amplified rDNA restriction analysis; FAME, fatty acid methyl ester.

The EMBL accession numbers for the 16S rRNA gene sequence of $B$. fumarioli strain LMG $17489^{\top}$ is AJ250056. The accession numbers for the other 16S rRNA gene sequences are: LMG 17492, AJ250057; LMG 18409, AJ250058; LMG 18418, AJ250059; LMG 18419, AJ250317; LMG 18435, AJ250318; LMG 18437, AJ250319.
}

to be found in a number of circumpolar islands, including Deception Island, the South Sandwich Islands, Bouvetøya, Marion Island and îles Kerguelen, and on continental Antarctica at Mount Erebus on Ross Island, Mount Melbourne and Mount Rittmann in northern Victoria Land, and in Marie Byrd Land (Fig. 1a).

Mounts Erebus and Melbourne represent two of the four provinces of the McMurdo Volcanic Group, which is one of the most extensive alkali volcanic provinces in the world (Harrington, 1958). In 19881989, the 4th Italian Antarctic Expedition discovered a new volcano, Mt Rittmann (Armienti \& Tripodo, 1991) (Fig. 1b), in the Melbourne Province, and in 1990-1991 the 6th Italian Expedition found fumaroles in a minor calderic structure of Mt Rittmann $\left(73^{\circ} 28^{\prime} \mathrm{S}\right.$, $165^{\circ} 36^{\prime} \mathrm{E}$; Bonaccorso et al., 1991). This geothermal site, and others at the summits of Mt Melbourne and Mt Erebus, harbour unique vegetation communities which appear to have formed following colonization by propagules from circumpolar continents (Linskens et al., 1993). The geothermally heated biosystem at Mt 
(a)

$0^{\circ}$. Bouvetøya

CANDLEMAS ISLAND

$\rightarrow \quad$ South Sandwich

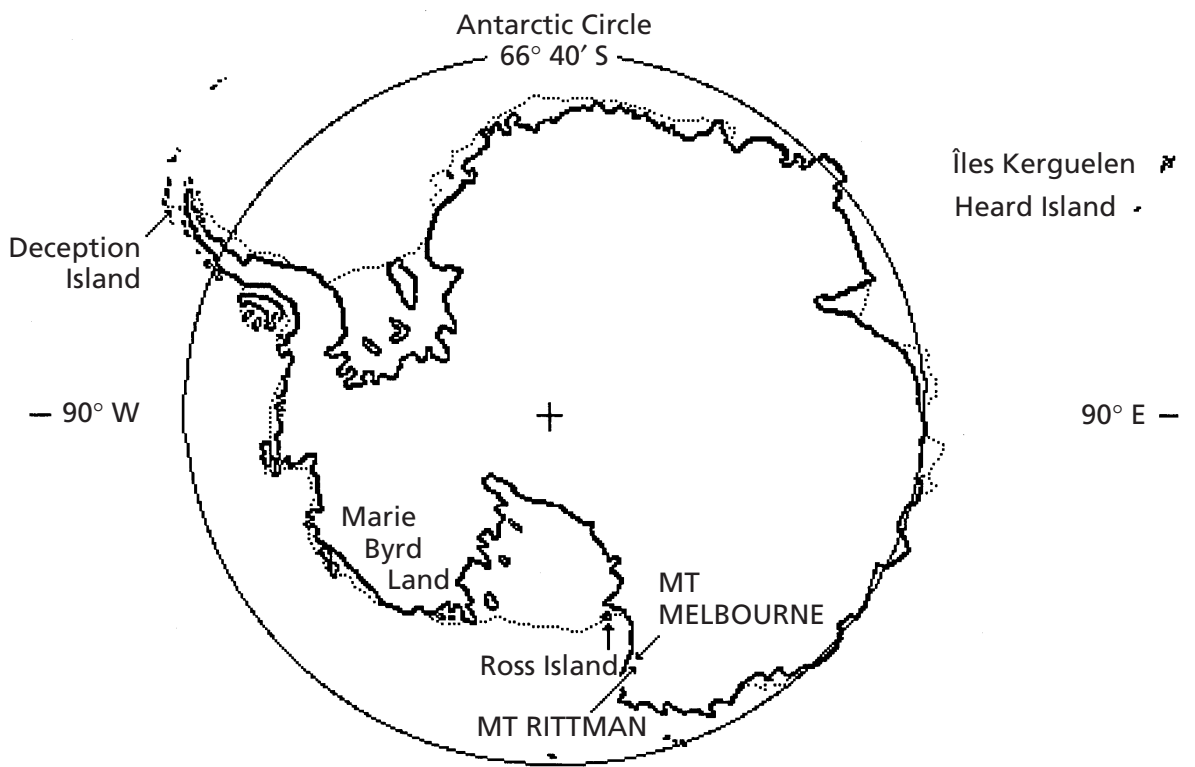

$180^{\circ}$

(c)

$1000 \mathrm{~km}$
- Marion Island

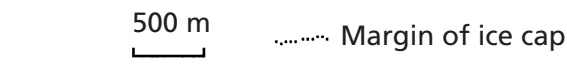

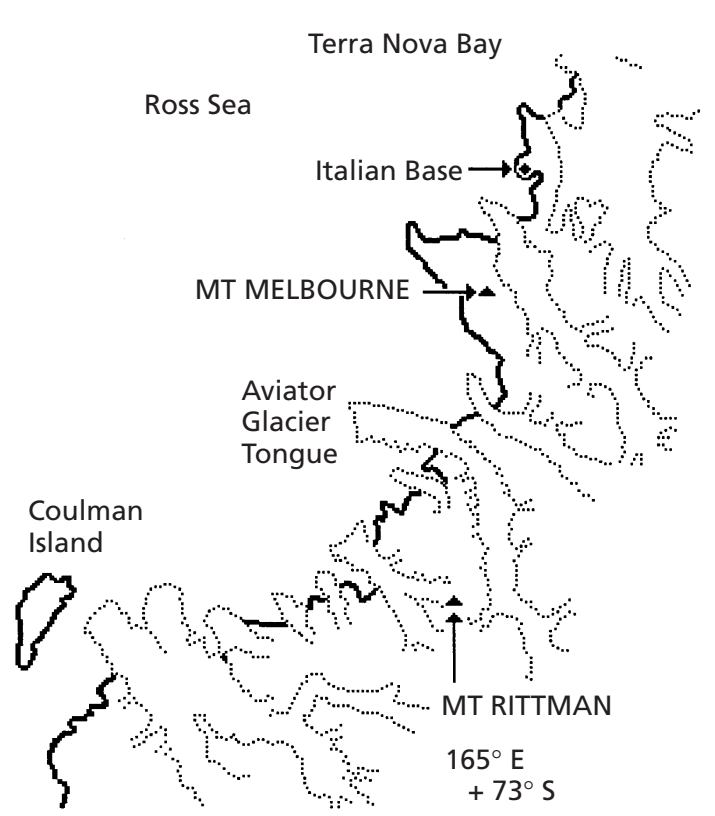

(b)

$50 \mathrm{~km}$

$50 \mathrm{~km}$

Glaciers 
Rittmann has been described by Bargagli et al. (1996). It is a rough slope of gravelly sand which lies at an altitude of about $2600 \mathrm{~m}$, and which has small fumaroles whose internal temperatures (at $10 \mathrm{~cm}$ depth) range between 50 and $63{ }^{\circ} \mathrm{C}$; patches of moss grow on the warm soil which has a relatively high moisture content (by Antarctic standards) and a $\mathrm{pH}$ of around $5 \cdot 4$.

Lucifer Hill on Candlemas Island $\left(57^{\circ} 05^{\prime} \mathrm{S}, 26^{\circ} 40^{\prime} \mathrm{W}\right.$; Fig. 1c), in the South Sandwich Islands, reaches an altitude of $232 \mathrm{~m}$ and also bears patches of moss around active fumaroles high on the hill, around inactive fumaroles at Clinker Gulch, and on lava soils at the base of the volcanic cone, with temperatures ranging from $85^{\circ} \mathrm{C}$ down to $0{ }^{\circ} \mathrm{C}$.

Soil samples were collected from Mt Melbourne and the Mt Rittmann geothermal site by British Antarctic Survey (BAS) members of the international BIOTEX 1 expedition during the 1995-1996 austral summer, and from Lucifer Hill, Candlemas Island, by BAS personnel during the 1996-1997 season, with a view to investigating the aerobic endospore-forming bacterial floras of these sites. The present paper describes the isolation and characterization of heterotrophic strains isolated from soils whose temperatures ranged from 0 to $60{ }^{\circ} \mathrm{C}$ on Candlemas Island, and from fumarole soil at $50{ }^{\circ} \mathrm{C}$ from Mt Rittmann. A moderately thermophilic and acidophilic, aerobic endospore-forming organism appeared to dominate the heterotrophic population of the Mt Rittmann fumarole soil samples, and was also found in soil taken from a cold, dead fumarole at Clinker Gulch, Candlemas Island; further strains were isolated from soils of Mt Rittmann and Cryptogam Ridge, Mt Melbourne ( $74^{\circ} 22^{\prime} \mathrm{S}$, $164^{\circ} 40^{\prime} \mathrm{E}$; Broady et al., 1987) during the 1998-1999 austral summer. We propose this organism as a new species with the name Bacillus fumarioli.

\section{METHODS}

Isolation and maintenance of strains. Duplicate soil samples of roughly $500 \mathrm{~g}$ were collected aseptically from (i) a fumarole on Mt Rittmann (Fig. 1b; altitude $2600 \mathrm{~m}$; internal temperature of fumarole $50{ }^{\circ} \mathrm{C}$ at $10 \mathrm{~cm}$ depth), (ii) geothermally heated soil on the north-west ridge of $\mathrm{Mt}$ Melbourne (Fig. 1b; altitude $2500 \mathrm{~m}$ ) during the 1995-1996 austral summer, and (iii) six sites on Lucifer Hill, Candlemas Island (Fig. 1c): two active fumaroles (sites 1 and 2, temperature range $30-60{ }^{\circ} \mathrm{C}$ ) at the top of the cone (altitude $232 \mathrm{~m}$ ), two cold, dead fumaroles (sites 3 and 4; temperature range $10-20{ }^{\circ} \mathrm{C}$ and $0-15{ }^{\circ} \mathrm{C}$ respectively; altitude $20 \mathrm{~m}$ ) in Clinker Gulch, and two other areas of unheated ground (sites 5 and 6 ; temperature range $0-15^{\circ} \mathrm{C}$; altitude $30 \mathrm{~m}$ ) at the foot of the hill, during the 1996-1997 austral summer. One of the sample duplicates from each site was stored chilled (about $4{ }^{\circ} \mathrm{C}$ ) and the other was deep-frozen (about $-20^{\circ} \mathrm{C}$ ) between collection in the Antarctic and study in Glasgow. Ten samples of mossy and moss-free soils from $\mathrm{Mt}$ Rittmann (soil temperature range $8.3-58.5^{\circ} \mathrm{C}$, and $62.5^{\circ} \mathrm{C}$ at $5 \mathrm{~cm}$ depth within a fumarole), and eight samples of mossy and moss-free soils from Cryptogam Ridge (altitude $2700 \mathrm{~m}$, soil temperatures $3 \cdot 2-42 \cdot 0^{\circ} \mathrm{C}$ and $47 \cdot 0^{\circ} \mathrm{C}$ at $5 \mathrm{~cm}$ depth within a fumarole) and two samples of moss-free soil from the NW ridge of Mt Melbourne (soil temperatures 28.0 and $36.7^{\circ} \mathrm{C}$ ) collected during the 1998-1999 austral summer were used fresh for isolations and counts of moderately thermoacidophilic bacteria when examined at the Terra Nova Bay base laboratory as soon as possible after collection, and then stored frozen for transit to Glasgow. Soil samples (temperatures ranging from $-1.0{ }^{\circ} \mathrm{C}$ to $+16.5^{\circ} \mathrm{C}$ ) were also collected from 25 non-geothermal sites within a $50 \mathrm{~km}$ radius of Mt Melbourne during the 1998-1999 season. Aerobic endospore-forming bacteria were sought in the 1995-1996 and 1996-1997 samples by adding $1 \mathrm{~g}$ quantities of soil to $9 \mathrm{ml}$ Trypticase Soy Broth (TSB; Oxoid) in duplicate at $\mathrm{pH} 5.5$ and 7.0 for $\mathrm{Mt}$ Rittmann and $\mathrm{Mt}$ Melbourne samples, and at $\mathrm{pH} 4 \cdot 5,5.5$ and 6.5 for Candlemas Island samples, and heat-treating one of each pair at $80{ }^{\circ} \mathrm{C}$ for $10 \mathrm{~min}$ to kill vegetative cells. Spread plates inoculated with $0 \cdot 1 \mathrm{ml}$ soil suspension on Trypticase Soy Agar (Oxoid) at the appropriate $\mathrm{pH}$ and with $5 \mathrm{mg}^{-1}$ $\mathrm{MnSO}_{4}$ to enhance sporulation (TSA $\mathrm{MnSO}_{4}$ ) were incubated at $15,30,50$ and $65^{\circ} \mathrm{C}$ for Mt Rittmann samples and at $20,30,40,50$ and $60^{\circ} \mathrm{C}$ for Candlemas Island samples, and the suspensions remaining were incubated at the same range of temperatures in waterbaths. The 1998-1999 samples from Mt Rittmann and Mt Melbourne and from 25 other sites were cultivated at $50^{\circ} \mathrm{C}$ in a modification of the medium B described by Nicolaus et al. (1998), here called Bacillus fumarioli broth (BFB), and plated on a solid medium called Bacillus fumarioli agar (BFA). BFB contained $4 \mathrm{~g}$ yeast extract, $2 \mathrm{~g}\left(\mathrm{NH}_{4}\right)_{2} \mathrm{SO}_{4}, 3 \mathrm{~g} \mathrm{KH}_{2} \mathrm{PO}_{4}$ and $4 \mathrm{ml}$ each of solutions $\mathrm{A}$ and $\mathrm{B} 1^{-1}\left[\mathrm{~A}, 125 \mathrm{~g}\left(\mathrm{NH}_{4}\right)_{2} \mathrm{SO}_{4}, 50 \mathrm{~g}\right.$ $\mathrm{MgSO}_{4} .7 \mathrm{H}_{2} \mathrm{O}^{-1} ; \mathrm{B}, 62 \cdot 5 \mathrm{~g} \mathrm{CaCl}_{2} .2 \mathrm{H}_{2} \mathrm{O}^{-1}$, adjusted to

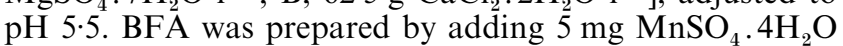
and 18 g agar $1^{-1}$ to BFB prior to autoclaving. TSB and BFB cultures which became turbid were subcultured by streaking onto TSA $\mathrm{MnSO}_{4}$ or BFA at the appropriate $\mathrm{pH}$, and incubating at the appropriate temperature. Colonies appearing on spread plates and streak plates were screened for vegetative and sporangial morphologies by phase-contrast microscopy, and endospore-forming rods were streak purified and then transferred to slopes of the same medium for storage at $4{ }^{\circ} \mathrm{C}$ after incubation and confirmation of sporulation by microscopy. Proportions of spores and vegetative cells of the moderately thermoacidophilic endospore-former in five 1998-1999 Mt Rittmann soils, taken from one area of loose, moss-free soil about $2 \mathrm{~m}$ in diameter and showing a range of temperatures $\left(8 \cdot 3,14 \cdot 5,28,42 \cdot 2\right.$ and $\left.58.5^{\circ} \mathrm{C}\right)$, were determined by BFA plate counts of duplicate soil suspensions of $1 \mathrm{~g}$ soil crumbs in $9 \mathrm{ml}$ quarter-strength Ringer's solution, one of which was heated at $80^{\circ} \mathrm{C}$ for $10 \mathrm{~min}$ to destroy vegetative cells prior to plating and incubation at $50{ }^{\circ} \mathrm{C}$.

DNA preparation. For amplified rDNA restriction analysis (ARDRA), total genomic DNA was purified using a slight modification of the method of Pitcher et al. (1989), as described previously (Heyndrickx et al., 1995, 1996). For DNA-DNA binding experiments and DNA base composition studies, DNA was prepared using a combination of the methods of Marmur (1961) and Pitcher et al. (1989), as described by Heyndrickx et al. (1995). A compiled description follows: (all buffers and aqueous solutions were prepared with autoclaved MilliQ-water) exponentially growing cells $(0.75-1.5 \mathrm{~g})$ were harvested from cultures on solid media in $14 \mathrm{~cm}$ diameter Petri dishes and suspended in $15 \mathrm{ml} \mathrm{RS}$ buffer (Resuspension buffer contained $0.15 \mathrm{M}$ $\mathrm{NaCl}$, and 0.01 M EDTA at $\mathrm{pH} 8 \cdot 0$ ). After centrifugation, 
the cell pellet was resuspended in $3 \mathrm{ml}$ lysozyme solution (50 $\mathrm{mg}$ lysozyme $\mathrm{ml}^{-1}$ ) and $60 \mu \mathrm{l}$ RNase solution $(10 \mathrm{mg}$ RNase $\mathrm{ml}^{-1}$ ) and incubated for $1 \mathrm{~h}$ at $37^{\circ} \mathrm{C}$. Cells were lysed by adding $15 \mathrm{ml}$ GES ( $10 \mathrm{~g}$ guadinium isothiocyanate $/ 0.5 \mathrm{M}$ EDTA at pH 8.0/1 g Sarkosyl, made up to $100 \mathrm{ml}$ ) reagent after gentle shaking. Cooling in ice water for $15 \mathrm{~min}$ was followed by addition of $7.5 \mathrm{ml}$ ammonium acetate $(578.1 \mathrm{~g}$ ammonium acetate $1^{-1}$; filter-sterilized), gentle shaking and another $15 \mathrm{~min}$ in ice. The crude DNA extract was mixed with $15 \mathrm{ml}$ of a cold chloroform-isoamyl alcohol mixture (24:1 ratio). The solution was then vigorously shaken and centrifuged $(20 \mathrm{~min}$ at $15000 \mathrm{~g}$ ). The supernatant was carefully transferred to a plastic vial and the DNA was precipitated by adding 0.54 vols 2-propanol. The precipitated DNA was twisted on a glass rod and washed in an ethanol gradient $(70,85$ and $90 \%, \mathrm{v} / \mathrm{v})$, air-dried, and dissolved in $15 \mathrm{ml}$ TE (Tris/HCl/EDTA) buffer. After an additional RNase ( $75 \mu \mathrm{l}$ of $\left.10 \mathrm{mg} \mathrm{RNase} \mathrm{ml}^{-1}\right)$ treatment of $1 \mathrm{~h}$ at $37^{\circ} \mathrm{C}, 625 \mu \mathrm{l}$ acetate EDTA ( $3 \mathrm{M}$ ammonium acetate, $1 \mathrm{mM}$ EDTA, $\mathrm{pH} 7.5$ ) was added. Addition of $5 \mathrm{ml}$ chloroform and a 20 min centrifugation at $10000 \mathrm{~g}$ separated the protein fraction from the water phase containing the DNA. To the latter, 2 vols $95 \%(\mathrm{v} / \mathrm{v})$ denatured ethanol were added in a separate vial to precipitate the highmolecular-mass DNA which was twisted on a glass rod, airdried, washed in an ethanol gradient $(70,80$ and $90 \%, \mathrm{v} / \mathrm{v}$, ethanol in water) and dissolved in $5 \mathrm{ml}$ of $0 \cdot 1 \times \mathrm{SSC}$. DNA solutions were stored at $-80^{\circ} \mathrm{C}$.

ARDRA. Enzymically amplified $16 \mathrm{~S}$ rDNA was obtained by PCR and analysed by restriction digestion with five restriction enzymes (HaeIII, DpnII, RsaI, BfaI and Tru9I) as described previously (Heyndrickx et al., 1996). Identification of the Antarctic isolates was attempted by comparing ARDRA profiles with a database of over 1000 authentic strains of aerobic endospore-formers.

DNA base composition. DNA was enzymically degraded into nucleosides as described by Mesbah et al. (1989). The nucleoside mixture obtained was then separated by HPLC using a Waters Symmetry Shield C8 column thermostabilized at $37{ }^{\circ} \mathrm{C}$. The solvent was $0.02 \mathrm{M} \mathrm{NH}_{4} \mathrm{H}_{2} \mathrm{PO}_{4}(\mathrm{pH}$ $4.0)$ with $1.5 \%(\mathrm{v} / \mathrm{v})$ acetonitrile. Non-methylated lambda phage DNA (Sigma) was used as the calibration reference

DNA-DNA hybridizations. DNA-DNA hybridizations were performed with photobiotin-labelled probes in microplate wells as described by Ezaki et al. (1989), using a HTS7000 Bio Assay Reader (Perkin-Elmer) for the fluorescence measurements (excitation filter of $360 \mathrm{~nm}$, emission filter $465 \mathrm{~nm}$ ). The optimal renaturation temperature was determined according to the equation of De Ley et al. (1970).

$16 \mathrm{~S}$ rDNA sequencing. The following conserved sequences (primers) were used to amplify fragments of the 16S rRNA gene: A GTT TGA TCC TGG CTC AG (MH1); C TGG CTC AGG AC/TG AAC GCT G (ARI C/T); AGA GTT TGA TCC TGG CTC AG (pA); TAC CTT GTT ACG ACT TCA CCC CA (MH2) and AAG GAG GTG ATC CAG CCG CA (pH). The primer combinations used for the sequenced strains are shown in parentheses: LMG 17489 (MH1, MH2), LMG 17492 (ARI C/T, pH), LMG 18409 (pA, pH), LMG 18418 (pA, pH), LMG 18419 (ARI C/T, pH), LMG 18435 (pA, pH) and LMG 18437 (ARI C/T, pH). The PCR products were purified using a QIAquick PCR Purification Kit (Qiagen) according to the manufacturer's instructions. Sequencing was performed using an Applied Biosystems 377 DNA Sequencer and the protocols of the manufacturer (Perkin-Elmer Biosystems) using the ABI
Prism Dye and/or Big Dye Terminator Cycle Sequencing Ready Reaction Kit. The sequencing primers used were as in Coenye et al. (1999). The sequences of strains belonging to the same or different phylogenetic groups were retrieved from the EMBL database and aligned with the consensus sequence using GeneBase software version 1.0 (Applied Maths, Kortrijk, Belgium). A 16S rDNA tree was constructed using the GeneBase software. Type strains of a number of Bacillus species and relatives were selected based on FASTA searches (Pearson \& Lipman, 1988). If more than one sequence of the type strain of a species was available in the database, the most complete sequence (the lowest number of ambiguities and/or longest part of the 16S RNA gene sequenced) was chosen.

SDS-PAGE of whole-cell proteins. Cells were grown on TSA at $52{ }^{\circ} \mathrm{C}$ and $\mathrm{pH} 5 \cdot 5$, the SDS protein extracts prepared and electrophoresed according to Pot et al. (1994) and the data collected and interpreted as described by Vauterin \& Vauterin (1992).

Gas chromatographic analysis of methylated fatty acids (FAMEs). Cells were grown on TSA at pH 5.5 and $52{ }^{\circ} \mathrm{C}$. Details of harvesting and analysis can be found in Heyndrickx et al. (1998) and Vauterin et al. (1991). The standardized MIS database could not be used for identification because the growth conditions of the strains did not conform to the standard conditions prescribed by the manufacturer.

Phenotypic characterization and numerical analysis. At the beginning of this study all strains were grown and maintained on TSA $\mathrm{MnSO}_{4}$ at the $\mathrm{pH}$ of isolation, with incubation at the temperature of isolation. Subsequently, the isolates growing at $\mathrm{pH} 5.5$ at $50{ }^{\circ} \mathrm{C}$ were found to give improved growth when cultivated in BFB and better growth and sporulation on BFA, and these media were used throughout the remainder of the study. Isolates growing at $\mathrm{pH} 5.5$ and $50{ }^{\circ} \mathrm{C}$ were grown for $24-72 \mathrm{~h}$ at $50^{\circ} \mathrm{C}$ on BFA and vegetative cells and sporangia were observed by phasecontrast microscopy for presence of motile cells, chains of cells, curved rods, rods with tapered ends, vacuoles, spores, swollen sporangia, parasporal crystals, parasporal bodies, shape of spores ellipsoidal, cylindrical or spherical, position of spores terminal, subterminal or central/paracentral; these strains were also examined for haemolysis on $5 \%$ horse blood using Columbia Blood Agar base (Oxoid), and for casein and starch hydrolysis, egg yolk reaction, and $\mathrm{NaCl}$ sensitivity using the methods of Gordon et al. (1973) but with media adjusted to $\mathrm{pH} 5 \cdot 5$, inoculating with overnight cultures in TSB, and incubating at $50^{\circ} \mathrm{C}$. Maximum and minimum growth temperatures were determined by incubating $10 \mathrm{ml}$ BFB cultures in waterbaths set to $30,37,40,45$, $50,55,60$ and $65^{\circ} \mathrm{C}$, and $\mathrm{pH}$ ranges for growth were determined using $10 \mathrm{ml} \mathrm{BFB}$ cultures adjusted to $\mathrm{pH} 4 \cdot 0,4 \cdot 5$, $5 \cdot 0,5 \cdot 5,6 \cdot 0,6 \cdot 5$ and $7 \cdot 0$; both series were examined for turbidity at $24 \mathrm{~h}$ intervals. Anaerobic growth was tested for by incubating cultures on BFA plates in a GasPak jar, with aerobically incubated plates as controls. Antibiotic sensitivity tests using Mastring discs (MAST Diagnostics) containing $25 \mu \mathrm{g}$ ampicillin, $50 \mu \mathrm{g}$ chloramphenicol, $100 \mu \mathrm{g}$ colistin sulphate, $30 \mu \mathrm{g}$ kanamycin, $30 \mu \mathrm{g}$ nalidixic acid, $50 \mu \mathrm{g}$ nitrofurantoin, $25 \mu \mathrm{g}$ streptomycin, and $100 \mu \mathrm{g}$ tetracycline were carried out on plates of Drug Sensitivity Test Agar (Oxoid) adjusted to $\mathrm{pH} 5.5$ and incubated at $50^{\circ} \mathrm{C}$. Strains were characterized using 49 carbohydrate tests in the API $50 \mathrm{CH}$ gallery. As the 50CHB suspension medium was unsuitable for these acidophilic strains, a medium was 
adapted from the one described by Deinhard et al. (1987); it was adjusted to $\mathrm{pH} 6$ and used $0.033 \%$ bromcresol purple as indicator. These phenotypic data were subjected to numerical analysis as described by Heyndrickx et al. (1998), but reference strains growing at pH 5.5-6.0 were not available.

Strains isolated at $\mathrm{pH} 6.0$ or 7.0 were characterized using API 20E and 50 CHB kits (bioMérieux) following the methods of Logan \& Berkeley (1984), but with modifications of incubation time according to the organisms' optimum growth temperatures. Strains growing at 20, 40, 50 and $60{ }^{\circ} \mathrm{C}$ were incubated for $36-72 \mathrm{~h}, 18-36 \mathrm{~h}$ and $12-24 \mathrm{~h}$ and $12-24 \mathrm{~h}$ respectively. Strains giving weak reactions in the API 20E and $50 \mathrm{CHB}$ kits were also characterized using the API Biotype 100 kit (Heyndrickx et al., 1997). Analysis of the data along with characters for two reference strains of each established species of Aneurinibacillus, Bacillus, Brevibacillus, Paenibacillus and Virgibacillus was performed in order to identify the strains, using the numerical method described by Heyndrickx et al. (1998).

\section{RESULTS}

\section{Isolation of strains}

Plates and broths inoculated from the 1995-1996 Mt Rittmann samples yielded aerobic endospore-formers at both $\mathrm{pH} 5.5$ and $7 \cdot 0$, and representative colonies were subcultured for further study. However, isolates obtained at $\mathrm{pH} 7 \cdot 0$, whose colonial and microscopic morphologies resembled those of isolates obtained at $\mathrm{pH} 5 \cdot 5$, did not survive subculture. No aerobic endospore-formers were isolated at either $\mathrm{pH}$ from the samples from the NW ridge of Mt Melbourne. No growth occurred at $65^{\circ} \mathrm{C}$ and no spore-formers were isolated from broths or plates at 15 and $30^{\circ} \mathrm{C}$. Large numbers of colonies of aerobic endospore-formers grew at $50{ }^{\circ} \mathrm{C}$ on $\mathrm{pH} 5.5$ plates, and 40 isolates of moderate thermoacidophiles representative of four colony types, designated L (large), S (small), Sm (smooth) and Ir (iridescent) were selected for further study. As polyphasic taxonomic analysis of these strains (see below) revealed a homogeneous group representing a new species, they are hereinafter referred to as B. fumarioli (Table 1). Plates and broths inoculated from Candlemas Island samples yielded a variety of aerobic endospore-formers, and the representatives selected for further study are also listed in Table 1, with identification results for strains isolated at $\mathrm{pH} 6.0$ or $7 \cdot 0$ shown in Table 2 . Further moderately thermoacidophilic strains, which have not yet been fully characterized, but whose growth conditions, colonies and microscopic morphologies identified them as $B$. fumarioli, were isolated from soils of Mt Rittmann and Cryptogam Ridge, Mt Melbourne, during the 19981999 austral summer, but not from the soils of the NW ridge of Mt Melbourne (two other kinds of aerobic endospore-former were isolated from this site; they appeared to be present in small numbers and to be difficult to cultivate, and their identities have not yet been investigated), or from the 25 soil samples collected from non-geothermal sites within a $50 \mathrm{~km}$ radius of $\mathrm{Mt}$ Melbourne. These further isolates of B. fumarioli were found in soils whose temperatures ranged from $3 \cdot 4$ to
$62.5{ }^{\circ} \mathrm{C}$, where they existed as both spores and vegetative cells, the proportions of sporulated cells tending to be higher at the temperature extremes $(9 \%$ at $8.3{ }^{\circ} \mathrm{C} ; 29 \%$ at $\left.58.5{ }^{\circ} \mathrm{C}\right)$, and lower $\left(3 \%\right.$ at $\left.42.5{ }^{\circ} \mathrm{C}\right)$ at temperatures approaching the optimum growth temperature $\left(50^{\circ} \mathrm{C}\right)$ of the organisms. The counts of vegetative cells of $B$. fumarioli were not confused by the appearance of many colonies of other organisms.

\section{ARDRA}

The 29 strains of B. fumarioli from the $1995-1996 \mathrm{Mt}$ Rittmann samples and from Candlemas Island were separated from all the other organisms studied in the numerical analysis of their combined ARDRA patterns (Fig. 2), and merge to form one large cluster at $85 \% \mathrm{~S}$. Six of the strains isolated from Candlemas Island (LMG 18467-18472) show $100 \%$ similarity and might be regarded as clonal; Mt Rittmann isolate LMG 18407 also shows $100 \%$ similarity with this group. These seven strains merge with seven $\mathrm{Mt}$ Rittmann isolates (LMG 18408-18411, 18413, 18415, 18416) at $97 \%$ similarity, so that the Mt Rittmann and Candlemas Island isolates do not appear to represent distinct lineages, yet there might be some phylogenetic diversity within the two populations.

\section{S rDNA sequencing}

The 16S rDNA sequences for strains LMG 17489 , LMG 17492, LMG 18409 and LMG 18418 showed high similarity (Fig. 3). The lowest sequence similarity in rDNA sequence, of $99.4 \%$, was found between $B$. fumarioli strains LMG 17489 from Mt Rittmann and LMG 17418 from Candlemas Island. The similarities between the 16S rDNA sequences of $B$. fumarioli LMG $17489^{\mathrm{T}}$ (EMBL accession no. AJ250056), $B$. fumarioli $\mathrm{LMG} 17492$ (AJ250057), B. fumarioli $\mathrm{LMG}$ 18409 (AJ250058) and B. fumarioli LMG 18418 (AJ250059) were at least $99 \cdot 8 \%$. A FASTA search indicated that the highest similarity between these four strains and sequences in the EMBL database was no more than $96.5 \%$ (with 'Bacillus pseudomegaterium'; EMBL accession number X77791). This observation supports a separate species rank for these Antarctic isolates.

The two Candlemas Island isolates LMG 18419 (AJ250317) and LMG 18437 (AJ250319) showed very high 16S rDNA sequence similarity (above $99 \%$ ) and seem to belong to a distinct species at the border of Paenibacillus (Fig. 3 ; similarity in $16 \mathrm{~S}$ rDNA sequence with established Paenibacillus species is $96 \%$ at most, according to a FASTA search in the EMBL database). Classification of these strains must wait until more strains of this putative new taxon become available. Strain LMG 18435 (AJ250318) also appeared to represent a new species (highest similarities were between $96.8 \%$ and $97.3 \%$ with Bacillus sporothermodurans entries in the EMBL database; accession nos U49078, U49079 and U49080), but classification must again await further strains. 
Table 1. Antarctic isolates studied and the methods used for characterization

Abbreviations: LMG, BCCM/LMG Bacteria Collection, Laboratorium voor Microbiologie Gent, Universiteit Gent, Belgium; Ir, iridescent colonies; L, large colonies; S, small colonies; Sm, smooth colonies; R, Mount Rittmann; c, chilled sample; f, frozen sample; $p$, heat-treated (pasteurized) sample; u, unpasteurized sample; SSI, South Sandwich Islands sample; numbers 1-6 in parentheses for SSI strains refer to sampling sites shown in Fig. 1(c).

\begin{tabular}{|c|c|c|c|c|c|c|}
\hline \multirow[t]{2}{*}{ Identity } & \multirow{2}{*}{$\begin{array}{l}\text { LMG } \\
\text { no. }\end{array}$} & \multirow{2}{*}{$\begin{array}{c}\text { Other } \\
\text { designation }\end{array}$} & \multirow[t]{2}{*}{ Source and isolation conditions* } & \multicolumn{3}{|c|}{ Methods applied $\dagger$} \\
\hline & & & & API & PAGE & FAME \\
\hline B. fumarioli & 17487 & Rcp L1 & Soil from active fumarole, Mt Rittmann, $\mathrm{pH} 5 \cdot 5,50^{\circ} \mathrm{C}$ & + & + & \\
\hline B. fumarioli & 17488 & Rfu L10 & Soil from active fumarole, Mt Rittmann, $\mathrm{pH} 5 \cdot 5,50^{\circ} \mathrm{C}$ & + & + & + \\
\hline B. fumarioli & $17489^{\mathrm{T}}+$ & Rcp Sm1 & Soil from active fumarole, Mt Rittmann, $\mathrm{pH} 5 \cdot 5,50^{\circ} \mathrm{C}$ & + & + & + \\
\hline B. fumarioli & 17490 & Rfu Sm10 & Soil from active fumarole, Mt Rittmann, $\mathrm{pH} 5 \cdot 5,50^{\circ} \mathrm{C}$ & + & + & + \\
\hline B. fumarioli & 17491 & Rcu Ir1 & Soil from active fumarole, Mt Rittmann, $\mathrm{pH} 5 \cdot 5,50^{\circ} \mathrm{C}$ & + & + & + \\
\hline B. fumarioli & $17492 \ddagger$ & Rcp S1 & Soil from active fumarole, Mt Rittmann, $\mathrm{pH} 5 \cdot 5,50^{\circ} \mathrm{C}$ & & + & + \\
\hline B. fumarioli & 17493 & Rcu Ir3 & Soil from active fumarole, Mt Rittmann, $\mathrm{pH} 5 \cdot 5,50^{\circ} \mathrm{C}$ & & + & + \\
\hline B. fumarioli & 17494 & Rfu S10 & Soil from active fumarole, Mt Rittmann, $\mathrm{pH} 5 \cdot 5,50^{\circ} \mathrm{C}$ & & + & + \\
\hline B. fumarioli & 18407 & Rcp L2 & Soil from active fumarole, Mt Rittmann, $\mathrm{pH} 5 \cdot 5,50^{\circ} \mathrm{C}$ & & + & \\
\hline B. fumarioli & 18408 & Rcu L4 & Soil from active fumarole, Mt Rittmann, $\mathrm{pH} 5 \cdot 5,50^{\circ} \mathrm{C}$ & & & \\
\hline B. fumarioli & $18409 \ddagger$ & Rcu L5 & Soil from active fumarole, Mt Rittmann, $\mathrm{pH} 5 \cdot 5,50^{\circ} \mathrm{C}$ & & + & + \\
\hline B. fumarioli & 18410 & Rcu L6 & Soil from active fumarole, Mt Rittmann, $\mathrm{pH} 5 \cdot 5,50^{\circ} \mathrm{C}$ & & + & + \\
\hline B. fumarioli & 18411 & Rfu L12 & Soil from active fumarole, Mt Rittmann, $\mathrm{pH} 5 \cdot 5,50^{\circ} \mathrm{C}$ & & & \\
\hline B. fumarioli & 18412 & Rcu Ir2 & Soil from active fumarole, Mt Rittmann, $\mathrm{pH} 5 \cdot 5,50^{\circ} \mathrm{C}$ & & + & + \\
\hline B. fumarioli & 18413 & Rcu Sm4 & Soil from active fumarole, Mt Rittmann, $\mathrm{pH} 5 \cdot 5,50^{\circ} \mathrm{C}$ & & + & + \\
\hline B. fumarioli & 18414 & Rcu Sm5 & Soil from active fumarole, Mt Rittmann, $\mathrm{pH} 5 \cdot 5,50^{\circ} \mathrm{C}$ & & & + \\
\hline B. fumarioli & 18415 & Rcu S3 & Soil from active fumarole, Mt Rittmann, $\mathrm{pH} 5 \cdot 5,50^{\circ} \mathrm{C}$ & & + & + \\
\hline B. fumarioli & 18416 & Rfu S7 & Soil from active fumarole, Mt Rittmann, $\mathrm{pH} 5 \cdot 5,50^{\circ} \mathrm{C}$ & & + & + \\
\hline B. fumarioli & 18417 & Rfu S9 & Soil from active fumarole, Mt Rittmann, $\mathrm{pH} 5 \cdot 5,50^{\circ} \mathrm{C}$ & & + & + \\
\hline B. fumarioli & 18430 & Rcu Sm3 & Soil from active fumarole, Mt Rittmann, $\mathrm{pH} 5 \cdot 5,50^{\circ} \mathrm{C}$ & & + & + \\
\hline B. fumarioli & 18431 & Rcu S4 & Soil from active fumarole, Mt Rittmann, $\mathrm{pH} 5 \cdot 5,50^{\circ} \mathrm{C}$ & & + & \\
\hline B. fumarioli & 18432 & Rcu S5 & Soil from active fumarole, Mt Rittmann, $\mathrm{pH} 5 \cdot 5,50^{\circ} \mathrm{C}$ & & + & + \\
\hline B. fumarioli & $18418 \ddagger$ & SSI009 & Soil from dead fumarole (3), Clinker Gulch, $\mathrm{pH} 5 \cdot 5,50^{\circ} \mathrm{C}$ & & + & + \\
\hline B. fumarioli & 18467 & SSI094 & Soil from dead fumarole (3), Clinker Gulch, $\mathrm{pH} 5 \cdot 5,50^{\circ} \mathrm{C}$ & & + & \\
\hline B. fumarioli & 18468 & SSI095 & Soil from dead fumarole (3), Clinker Gulch, $\mathrm{pH} 5 \cdot 5,50^{\circ} \mathrm{C}$ & + & + & + \\
\hline B. fumarioli & 18469 & SSI096 & Soil from dead fumarole (3), Clinker Gulch, $\mathrm{pH} 5 \cdot 5,50^{\circ} \mathrm{C}$ & + & + & + \\
\hline B. fumarioli & 18470 & SSI097 & Soil from dead fumarole (3), Clinker Gulch, $\mathrm{pH} 5 \cdot 5,50^{\circ} \mathrm{C}$ & & + & + \\
\hline B. fumarioli & 18471 & SSI098 & Soil from dead fumarole (3), Clinker Gulch, $\mathrm{pH} 5 \cdot 5,50^{\circ} \mathrm{C}$ & + & + & \\
\hline B. fumarioli & 18472 & SSI010 & Soil from dead fumarole (3), Clinker Gulch, $\mathrm{pH} 5 \cdot 5,50^{\circ} \mathrm{C}$ & + & + & \\
\hline Bacillus sp. & $18419 \ddagger$ & SSI018 & Soil from active fumarole (2), Lucifer Hill, $\mathrm{pH} 6,50^{\circ} \mathrm{C}$ & + & + & + \\
\hline Bacillus sp. & 18420 & SSI056 & Soil from active fumarole (2), Lucifer Hill, $\mathrm{pH} 5 \cdot 5,30^{\circ} \mathrm{C}$ & + & & \\
\hline Bacillus sp. & 18421 & SSI073 & Soil from lava area (6), Lucifer Hill, $\mathrm{pH} 5 \cdot 5,30^{\circ} \mathrm{C}$ & + & + & + \\
\hline Bacillus sp. & 18422 & SSI061 & Soil from active fumarole (1), Lucifer Hill, $\mathrm{pH} 6,30^{\circ} \mathrm{C}$ & + & & \\
\hline Bacillus sp. & 18423 & SSI064 & Soil from active fumarole (1), Lucifer Hill, $\mathrm{pH} 5 \cdot 5,30^{\circ} \mathrm{C}$ & + & & \\
\hline Bacillus sp. & 18424 & SSI086 & Soil from active fumarole (1), Lucifer Hill, $\mathrm{pH} 6,20^{\circ} \mathrm{C}$ & + & & \\
\hline Bacillus sp. & 18425 & SSI092 & Soil from dead fumarole (3), Clinker Gulch, $\mathrm{pH} 6,20^{\circ} \mathrm{C}$ & + & & \\
\hline Bacillus sp. & 18433 & SSI001 & Soil from active fumarole (1), Lucifer Hill, $\mathrm{pH} 6,60^{\circ} \mathrm{C}$ & + & + & \\
\hline Bacillus sp. & 18434 & SSI004 & Soil from active fumarole (2), Lucifer Hill, $\mathrm{pH} 6,60^{\circ} \mathrm{C}$ & + & & \\
\hline Bacillus sp. & $18435 \ddagger$ & $\mathrm{SSI} 024$ & Soil from lava area (6), Lucifer Hill, $\mathrm{pH} 5 \cdot 5,40^{\circ} \mathrm{C}$ & + & + & \\
\hline Bacillus sp. & 18436 & SSI038 & Soil from dead fumarole (3), Clinker Gulch, $\mathrm{pH} 5 \cdot 5,40^{\circ} \mathrm{C}$ & + & + & + \\
\hline Bacillus sp. & $18437 \ddagger$ & SSI048 & Soil from active fumarole (2), Lucifer Hill, $\mathrm{pH} 5 \cdot 5,40^{\circ} \mathrm{C}$ & + & + & + \\
\hline Bacillus sp. & 18438 & SSI027 & Soil from active fumarole (2), Lucifer Hill, $\mathrm{pH} 6,40{ }^{\circ} \mathrm{C}$ & + & & \\
\hline Bacillus sp. & 18439 & SSI068 & Soil from dead fumarole (4), Lucifer Hill, $\mathrm{pH} 6,30^{\circ} \mathrm{C}$ & + & + & + \\
\hline Bacillus sp. & 18440 & SSI074 & Soil from lava area (5), Lucifer Hill, $\mathrm{pH} 6,20^{\circ} \mathrm{C}$ & + & & \\
\hline Bacillus sp. & 18442 & SSI082 & Soil from lava area (5), Lucifer Hill, $\mathrm{pH} 6,20^{\circ} \mathrm{C}$ & + & & \\
\hline
\end{tabular}

* The $\mathrm{pH}$ and temperature given indicate isolation conditions and not the conditions of the site at the time of sampling.

$\uparrow$ ARDRA was applied to all strains. Abbreviations: API, tests in API System and other routine biochemical tests and morphological observations; FAMEs, fatty acid methyl esters; PAGE, PAGE of whole-cell proteins.

$\$$ Strain subjected to $16 \mathrm{~S}$ rDNA sequencing. 
Table 2. Identifications by ARDRA and API tests of strains of aerobic endospore-forming bacteria isolated at pH 6.0 or 7.0 from soils of Candlemas Island

\begin{tabular}{|c|c|c|c|c|c|}
\hline $\begin{array}{l}\text { LMG } \\
\text { no. }\end{array}$ & ARDRA & $\% \mathrm{~S}$ & API & $\% \mathrm{~S}$ & Identity \\
\hline 18419 & B. circulans & $85 \cdot 7$ & P. thiaminolyticus & $72 \cdot 5$ & Unidentified \\
\hline 18420 & B. cereus $\dagger$ & 100 & B. cereus & $90 \cdot 0$ & B. cereus \\
\hline 18421 & A. aneurinilyticus & $96 \cdot 0$ & Brevibacillus sp.* & $82 \cdot 5$ & A. aneurinilyticus \\
\hline 18422 & B. horikoshii & $89 \cdot 8$ & B. stearothermophilus & $77 \cdot 5$ & Unidentified \\
\hline 18423 & B. fusiformis & $97 \cdot 7$ & B. pasteurii/Sporosarcina ureae* & $82 \cdot 5$ & $\begin{array}{l}\text { B. sphaericus/ } \\
\text { B. fusiformis group }\end{array}$ \\
\hline 18424 & B. sphaericus & 100 & B. globisporus* & $87 \cdot 5$ & B. sphaericus group \\
\hline 18425 & B. cereus & 100 & B. cereus & $90 \cdot 0$ & B. cereus \\
\hline 18433 & ' $B$. thermodenitrificans' & $95 \cdot 5$ & $\begin{array}{l}\text { B. stearothermophilus/ } \\
\text { 'B. thermodenitrificans' }\end{array}$ & $82 \cdot 5$ & ' $B$. thermodenitrificans' \\
\hline 18434 & 'B. thermodenitrificans' & $95 \cdot 5$ & $\begin{array}{l}\text { B. stearothermophilus/ } \\
\text { 'B. thermodenitrificans' }\end{array}$ & $82 \cdot 5$ & ' $B$. thermodenitrificans' \\
\hline 18435 & P. thiaminolyticus & $93 \cdot 6$ & B. horikoshii & $90 \cdot 0$ & Unidentified \\
\hline 18436 & B. lentus & $93 \cdot 3$ & No reactions & & B. lentus \\
\hline 18437 & B. circulans & $87 \cdot 5$ & B. circulans & $80 \cdot 0$ & Atypical B. circulans \\
\hline 18438 & B. cereus & 100 & B. cereus & $90 \cdot 0$ & B. cereus \\
\hline 18439 & Unidentified & No score & B. circulans & $80 \cdot 0$ & Unidentified \\
\hline 18440 & B. badius & $86 \cdot 4$ & No reactions & & Unidentified \\
\hline 18442 & 'B. carotarum' & 100 & Aneurinibacillus sp. & $85 \cdot 0$ & Unidentified \\
\hline
\end{tabular}

* Strains characterized using API Biotype 100 kit; all other strains were characterized using the API 20E/50 CHB kits.

$\dagger$ Not shown in Fig. 2.

\section{PAGE}

In the numerical analysis of SDS-PAGE patterns of whole-cell proteins for 26 B. fumarioli strains (Fig. 4), all patterns showed similarities of $87 \%$ or greater. Four strains from Candlemas Island (LMG 18467, LMG 18468, LMG 18470 and LMG 18471) clustered at $96.5 \%$ similarity and this group merged with all the other $B$. fumarioli strains at $94 \%$ similarity or higher. The $26 \mathrm{~B}$. fumarioli isolates merged with the other Candlemas Island strains (those isolated at $\mathrm{pH} 6.0$ or $7 \cdot 0$ ) at about $77 \%$ similarity or lower. The reproducibility of the method is such that the observed subgrouping of the $B$. fumarioli strains is not significant above $93 \%$ similarity, and so, as with the ARDRA results, the patterns represent members of a distinct and homogeneous taxon.

\section{FAME}

The fatty acid profiles of $20 \mathrm{~B}$. fumarioli strains were very homogeneous and were used to calculate a mean fatty acid pattern. Fatty acid profiles of other strains of the same group were not used to calculate the mean because they showed low overall peak areas, which might lead to uncertain interpretation. Visual inspection of the analyses however did not show different patterns overall. The mean calculated FAME profile for $B$. fumarioli is (where fatty acid contents are given as percentage of total, fatty acids representing less than $1 \%$ of the total amount are omitted, and the standard deviations are shown in parentheses): iso- $\mathrm{C}_{15: 0}, 51 \cdot 34$ (2.98); anteiso- $\mathrm{C}_{15: 0}, 6.30(0.88)$; iso- $\mathrm{C}_{16: 0}, 5.98(0.98)$; anteiso- $\mathrm{C}_{16: 0}, 3.57(0.69)$; iso- $\mathrm{C}_{17: 0: \omega 10 c}, 1.98$ (1.53); iso- $\mathrm{C}_{17: 0}, 15 \cdot 70$ (2.61); anteiso- $\mathrm{C}_{17: 0}, 14 \cdot 01(2 \cdot 02)$. All these fatty acids are present in all strains except for iso$\mathrm{C}_{17: 0: \omega 10 c}$ which was absent from four out of the 20 strains used to calculate the mean value.

\section{DNA}

Strain LMG $17489^{\mathrm{T}}$ showed $96 \%$ DNA-DNA relatedness with LMG 18409 and $96.8 \%$ relatedness with LMG 17492; LMG 17492 and LMG 18409 showed $98 \%$ relatedness. Strain LMG 18418 from Candlemas Island showed only $60 \%$ DNA relatedness with each of the three Mt Rittmann isolates LMG $17489^{\mathrm{T}}$, LMG 17492 and LMG 18409, but for the present we propose to regard all four strains as belonging to a single species, as there are no outstanding phenotypic characters that might warrant the recognition of two closely related species. The $\mathrm{G}+\mathrm{C}$ values were LMG 17489, 40.7\% ; LMG 18409, 40.7\% ; LMG 17492, 40.5\%; LMG 18418, 40.6 mol\%. 

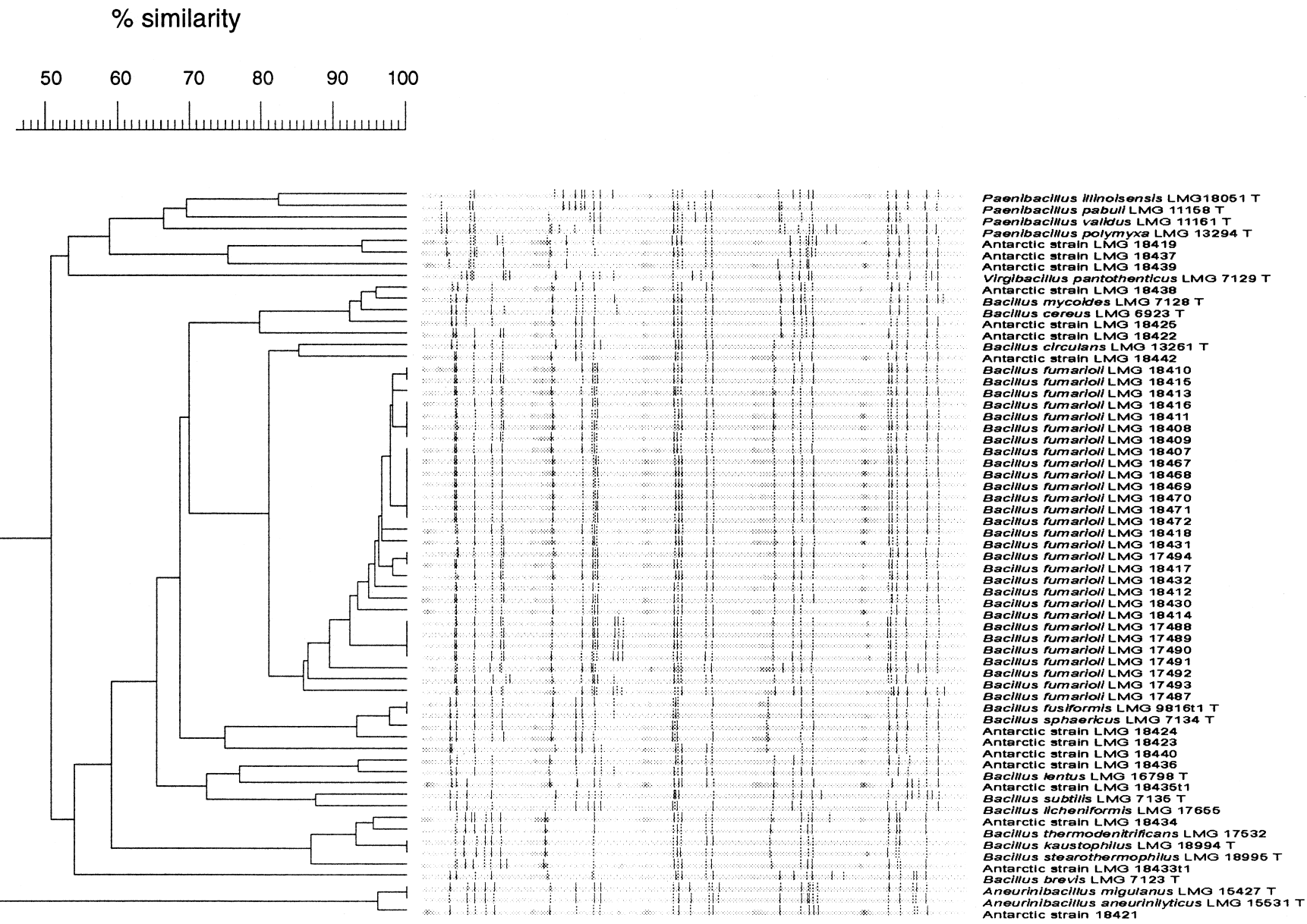

Fig. 2. Dendrogram based on UPGMA clustering of correlation coefficients of normalized 165 rDNA restriction profiles (ARDRA) of Antarctic isolates of aerobic endospore-forming bacteria and a selection of Bacillus (sensu lato) strains belonging to different rRNA groups.

\section{Phenotypic tests}

The nine strains of $B$. fumarioli which were subjected to phenotypic tests (Table 1) showed similar characters as summarized in Table 3 and in the description of $B$. fumarioli given below. Numerical analysis of these data (not shown) revealed a single cluster of these strains merging at $85 \% S_{\mathrm{G}}$, implying appreciable phenotypic diversity within the group but no subclustering suggestive of, for example, subspecific types associated with the two geographically distinct sources of the strains.

\section{Candlemas Island isolates growing at $\mathbf{p H} \mathbf{6 . 0}$ or $\mathbf{7 . 0}$}

As shown by Table 2, three strains (LMG 18420, LMG 18425 and LMG 18438) could confidently be identified as Bacillus cereus, and two strains (LMG 18433 and LMG 18434) were identified as 'Bacillus thermodenitrificans', which is a thermophile and a close relative of Bacillus stearothermophilus. Strain LMG 18437 was identified as Bacillus circulans by both methods, but it does not represent a typical strain of this species as similarities were low. Of the remaining ten strains, six
(LMG 18419, LMG 18422, LMG 18435, LMG 18439, LMG 18440, LMG 18442) gave different identifications by ARDRA and API tests and, as their similarities to reference strains were low in one or both of the analyses, they remain unidentified. A search of the EMBL sequence database also did not achieve clear-cut identification of strains LMG 18419, LMG 18435 and LMG 18437 on the basis of their 16S rDNA sequences. Strain LMG 18440 gave no reactions in API tests, and Bacillus badius (the identification given by ARDRA) is indeed an unreactive organism in phenotypic tests, but the similarity to B. badius in ARDRA is too low for confidence. Strain LMG 18436 also gave no reactions in API tests, but this is consistent with the ARDRA identification of Bacillus lentus (often a slow performer in phenotypic tests) at a high enough similarity to the reference strain for confidence that it might belong to this species. Strains LMG 18421, LMG 18423 and LMG 18424 showed high similarities to reference strains of Aneurinibacillus aneurinilyticus, Bacillus fusiformis and Bacillus sphaericus, respectively, in ARDRA; the identifications by API tests do not match the ARDRA results, but as 
$10 \%$ Dissimilarity

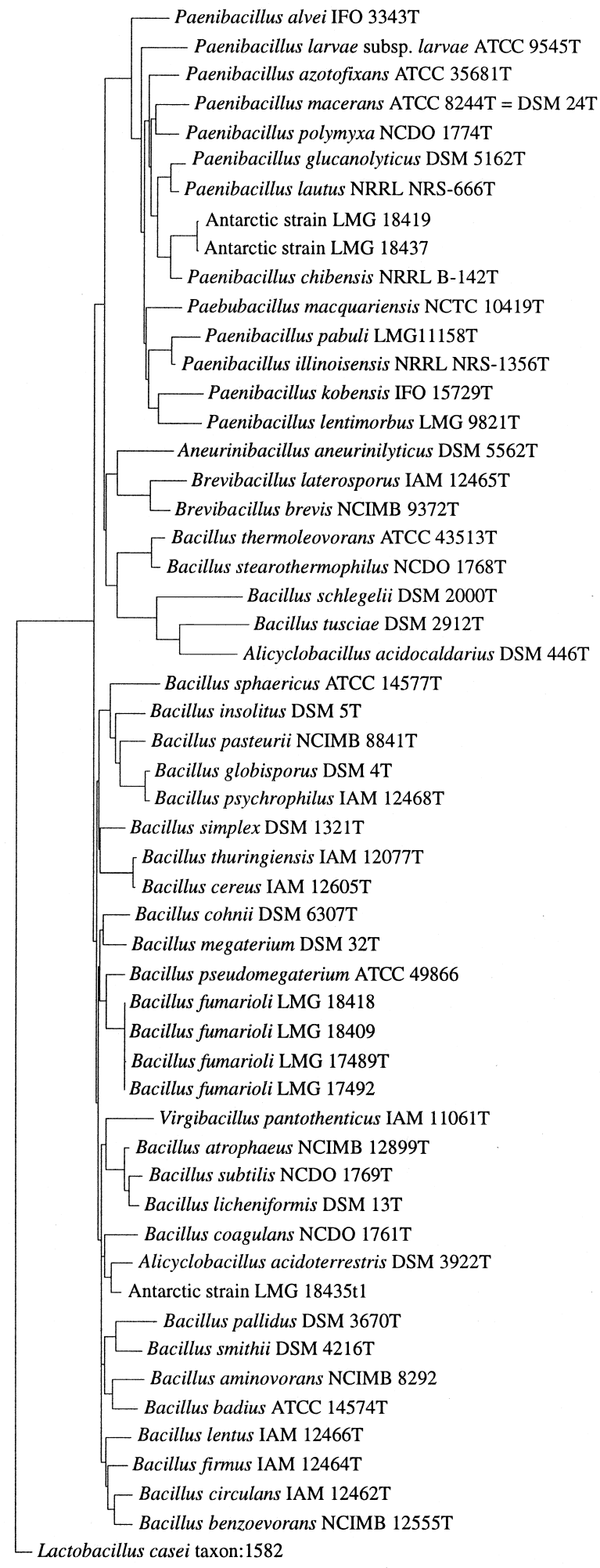

Fig. 3. Neighbour-joining clustering of $16 \mathrm{~S}$ rDNA sequences (rooted with Lactobacillus casei as reference) based on a selection of $16 \mathrm{~S}$ rDNA sequences from the EMBL database and $B$. fumarioli LMG $17489^{\top}, B$. fumarioli LMG 17492, B. fumarioli LMG 18409, B. fumarioli LMG 18418 and unnamed strains LMG 18435, LMG 18419 and LMG 18437. these organisms gave few positive reactions in the API kits, and were identified as close relatives of the species identified by ARDRA, the identifications by ARDRA may be accepted with confidence.

\section{DISCUSSION}

The B. fumarioli strains from Mt Rittmann and Candlemas Island showed similar profiles in ARDRA, PAGE, FAME and phenotypic analyses and are clearly members of a single species. It is of particular interest that the isolates from the two quite different environments which lie about $5600 \mathrm{~km}$ apart (that on Mt Rittmann being an active fumarole at an altitude of $2600 \mathrm{~m}$ and $40 \mathrm{~km}$ inland on the Antarctic continent, and that on Candlemas Island being a cold, dead fumarole lying close to sea level and being influenced by the Southern Ocean only about 300 m away), show similar phenotypic behaviour and substantial genotypic similarity (in $16 \mathrm{~S}$ rDNA sequence and overall DNA relatedness). This finding suggests that colonization of these two sites has been from a common source, and this is most likely to have occurred from the air as free spores or spores attached to plant propagules; birds are not known to visit Mt Rittmann and human visits to this site have only occurred since $1988 / 1989$ and not in conjunction with visits to Candlemas Island. Humans have only occasionally visited the latter site since its discovery by Captain James Cook in 1775, and a first survey by a BAS team in 1964, but its aerobic endospore-forming flora could owe something to contamination by humans.

The B. fumarioli strains we analysed were isolated from the 1995-1996 season's soil samples from Mt Rittmann and the 1996-1997 samples from Candlemas Island. The organism was then reisolated from all ten samples collected from Mt Rittmann, and from all eight samples collected from Cryptogam Ridge, $\mathrm{Mt}$ Melbourne, during the 1998-1999 season, but not from the 1995-1996 or 1998-1999 samples from the NW ridge of Mt Melbourne or from local, unheated soils. It is of special interest that the NW ridge of Mt Melbourne failed to yield the organism from samples taken on two occasions. Why this particular geothermal site, lying a short distance from Cryptogam Ridge (and apparently having a similar soil), should not yield $B$. fumarioli is not understood, and the nearabsence of moss from this site (Broady et al., 1987) is also unexplained, yet $B$. fumarioli was isolated from both mossy and moss-free areas of Cryptogam Ridge and Mt Rittmann. Broady et al. (1987) remarked on the low diversity of Victoria Land warm ground bryophytes compared with Deception Island and the South Sandwich Islands in maritime Antarctica. They noted that the geothermal areas of Mt Erebus and Mt Melbourne are, in comparison with maritime Antarctica, much further from the rich propagule sources of more temperate lands to the north and west; nonetheless, the northern Victoria Land volcanoes do lie in the tracks of cyclonic depressions spiralling southwards over the Southern Ocean and so might readily 
$\%$ Similarity

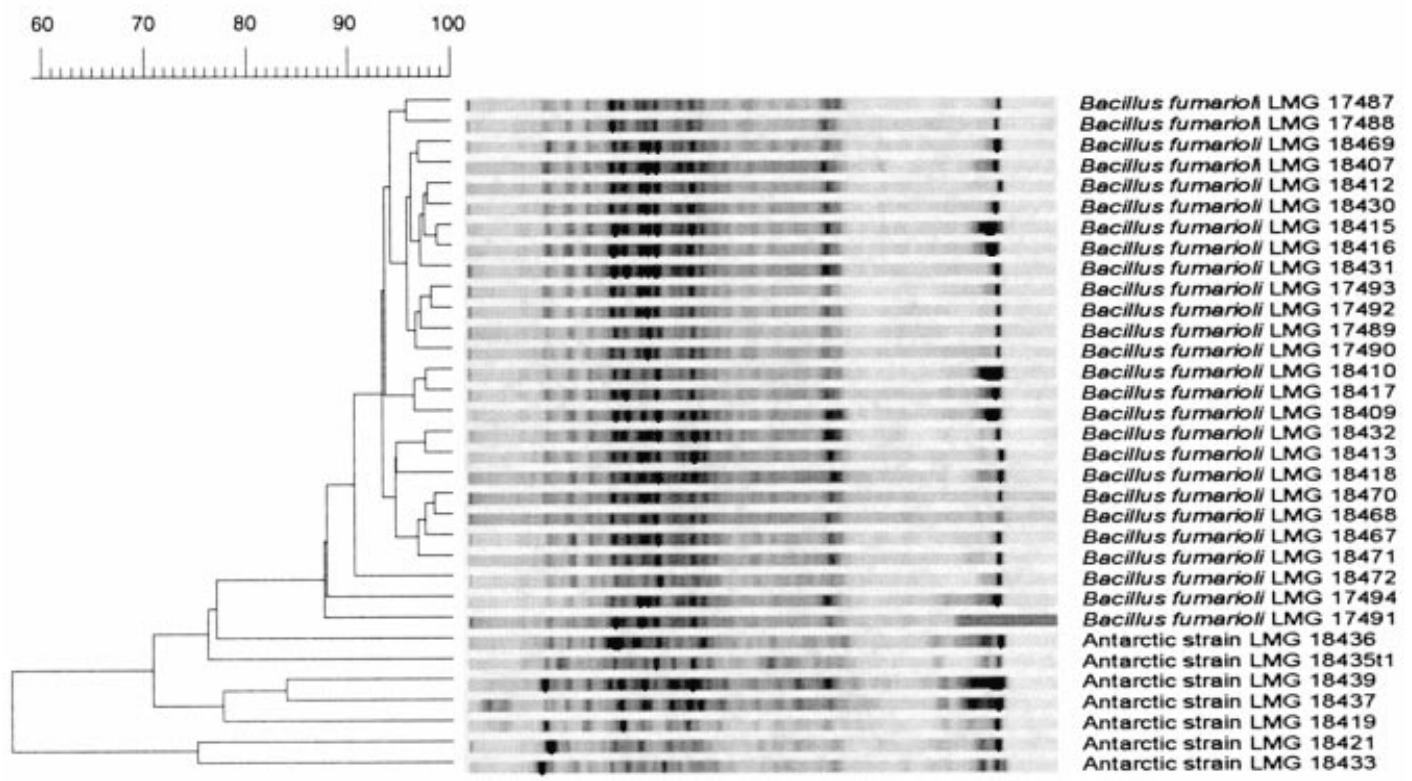

Fig. 4. Normalized computer profiles from SDS-PAGE analyses of whole-cell proteins of Antarctic isolates. The dendrogram is based on UPGMA clustering of the correlation coefficient $(r)$ of the total protein profiles. The zone used for clustering was between point 30 and point 330 (a complete lane contains 400 points). The subculture of strain LMG 18335 contained two types ( $\mathrm{t} 1$ and $\mathrm{t} 2$ ) with slightly different patterns (two bands different). Only t1 is included in the figure.

Table 3. Characters for differentiating some thermotolerant and thermophilic Alicyclobacillus and Bacillus species

Data from Bonjour \& Aragno (1984), Claus \& Berkeley (1986), Gordon et al. (1973), Nicolaus et al. (1996, 1998), Schenk \& Aragno (1979), Suzuki et al. (1983), White et al. (1993), Zarilla \& Perry (1987). Species: 1, B. fumarioli; 2, 'A. acidocaldarius subsp. rittmannii'; 3, 'B. thermoantarcticus'; 3, B. tusciae; 4, B. schlegelii; 5, B. coagulans; 6, B. stearothermophilus; 7, 'B. thermodenitrificans'; 9 , B. thermoglucosidasius; $10, B$. thermoleovorans.,$+>85 \%$ positive;,$- 0-15 \%$ positive; W, weak positive reaction; $\mathrm{V}$, varies within strains; d, varies between strains; NR, not reported; for spore shape: C, cylindrical, E, ellipsoidal; S, spherical; for spore position: C, central or paracentral; ST, subterminal; T, terminal.

\begin{tabular}{|c|c|c|c|c|c|c|c|c|c|c|}
\hline \multirow[t]{2}{*}{ Character } & \multicolumn{10}{|c|}{ Species } \\
\hline & 1 & 2 & 3 & 4 & 5 & 6 & 7 & 8 & 9 & 10 \\
\hline \multicolumn{11}{|l|}{$\begin{array}{l}\text { Growth temperature } \\
\left({ }^{\circ} \mathrm{C}\right)\end{array}$} \\
\hline Maximum & 55 & 70 & 65 & $<65$ & $<80$ & $55-60$ & $65-75$ & 70 & 69 & 70 \\
\hline Optimum & 50 & 63 & 63 & 55 & 70 & $36-43$ & 68 & $65-68$ & $61-63$ & $55-65$ \\
\hline Minimum & $25-30$ & 45 & 37 & 47 & $>37$ & $15-25$ & $30-45$ & $<65$ & 42 & 45 \\
\hline pH range & $4 \cdot 0-6 \cdot 5$ & $2 \cdot 5-5 \cdot 0$ & $5 \cdot 5-9 \cdot 0$ & $3 \cdot 5-6 \cdot 0$ & NR & $4 \cdot 0->6.8$ & $>5.7->6.8$ & $5 \cdot 5-\mathrm{NR}$ & $<6.5-8.7$ & $6 \cdot 2-7 \cdot 5$ \\
\hline Optimum pH & $5 \cdot 5$ & $4 \cdot 0$ & $6 \cdot 0$ & $4 \cdot 5$ & $6 \cdot 0-7 \cdot 0$ & 6.0 & $6 \cdot 0-6 \cdot 5$ & $6 \cdot 0$ & 6.5 & $6 \cdot 2-7 \cdot 5$ \\
\hline Motility & + & - & + & + & + & + & + & - & $\mathrm{d}$ & - \\
\hline Spore shape & $\mathrm{E} / \mathrm{C}$ & $\mathrm{E}$ & E & $\mathrm{E}$ & $\mathrm{S}$ & $\mathrm{E}$ & $\mathrm{E}$ & $\mathrm{E}$ & $\mathrm{E}$ & E \\
\hline Spore position & $\mathrm{C} / \mathrm{ST}$ & $\mathrm{C} / \mathrm{T}$ & $\mathrm{T}$ & ST & $\mathrm{T}$ & $\mathrm{ST} / \mathrm{T}$ & $\mathrm{ST} / \mathrm{T}$ & $\mathrm{T} / \mathrm{ST}$ & $\mathrm{T}$ & $\mathrm{T}$ \\
\hline Sporangia swollen & - & - & NR & + & + & V & + & + & + & + \\
\hline Anaerobic growth & - & + & - & - & - & + & - & + & + & - \\
\hline Nitrate reduction & - & W & - & + & + & d & $\mathrm{d}$ & + & + & + \\
\hline Gelatin hydrolysis & + & - & + & NR & - & - & + & d & - & NR \\
\hline Casein hydrolysis & - & - & - & NR & - & $\mathrm{d}$ & $\mathrm{d}$ & $\mathrm{d}$ & + & NR \\
\hline $\begin{array}{l}\mathrm{G}+\mathrm{C} \text { mol } \% \text { of type } \\
\text { strain }\end{array}$ & $40 \cdot 7$ & $64 \cdot 3$ & $53 \cdot 7$ & $57 \cdot 7$ & $64 \cdot 4$ & $47 \cdot 1$ & $51 \cdot 9$ & $52 \cdot 2$ & 45 & 58 \\
\hline
\end{tabular}




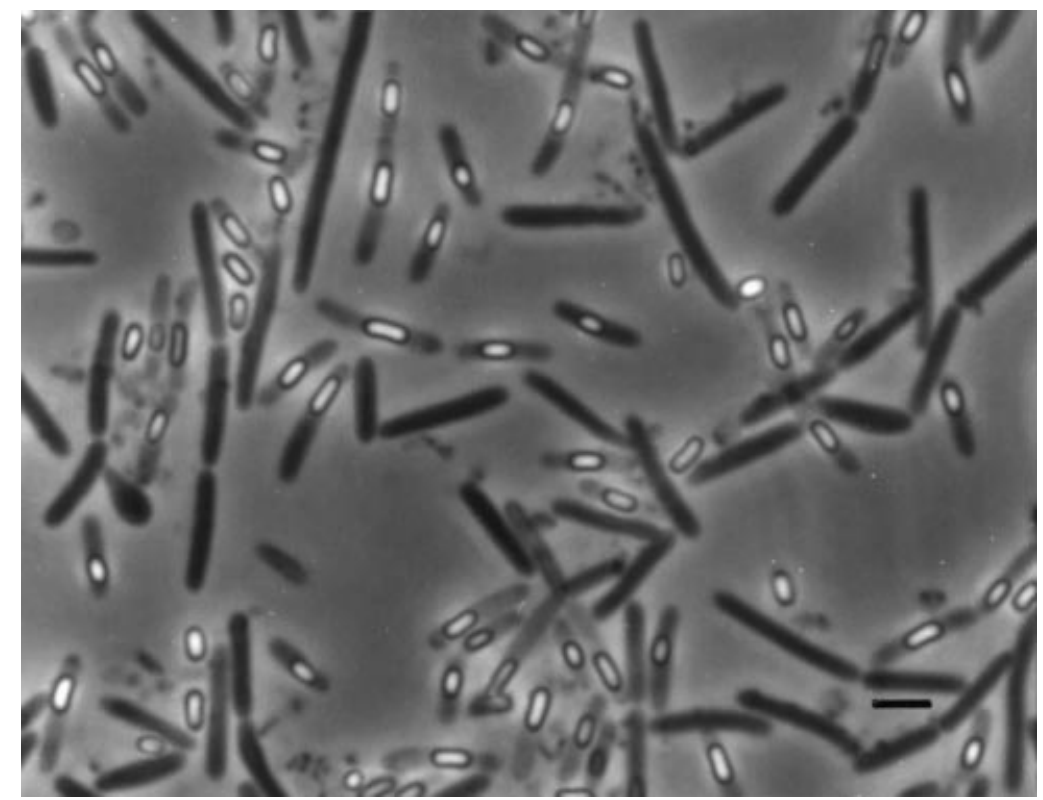

Fig. 5. Photomicrograph of sporangia and vegetative cells of the type strain of $B$. fumarioli viewed by phase-contrast microscopy; ellipsoidal and cylindrical spores lie paracentrally and subterminally in unswollen sporangia. Bar, $2 \mu \mathrm{m}$.

receive exotic propagules from temperate regions (Wynn-Williams, 1991). Other possible reasons for the observed low diversity are that both of the Victoria Land volcanoes have been vigorously active within the past few hundred years (Nathan \& Schulte, 1967; Bonaccorso et al., 1991), that propagules would experience harsher conditions in transit to these sites (in comparison with maritime Antarctic sites), and that long periods of darkness on warm, moist soils may be inimical to some potential colonists. Broady et al. (1987) also reported that none of the local cold-ground bryophytes of Victoria Land had colonized the volcanoes and inferred that the soil chemistry of the fumarole environment might be unsuitable, as dispersal problems would not seem to be great. It is remarkable, therefore, to find $B$. fumarioli in soils of both Victoria Land and maritime Antarctica (Candlemas Island), and noteworthy that it was not isolated from 25 cold soils local to Mt Melbourne, especially as the Candlemas Island soil yielding the organism was not geothermally active at the time of sampling. Llarch et al. (1997) did not find B. fumarioli in their geothermal soils from Deception Island, but they did not cultivate at $\mathrm{pH} 5.5$ from their samples.

It is notable for the Candlemas Island strains growing at $\mathrm{pH} 6$ or 7 that only eight of the 16 isolates examined received similar identifications by ARDRA and phenotypic analysis, and that six remained unidentifiable. Although the unidentified isolates may represent new taxa or atypical members of established taxa, as Llarch et al. (1997) found on Deception Island, further isolates would need to be isolated and examined before any taxonomic conclusions could be drawn.
In conclusion, our polyphasic data show that the moderately thermoacidophilic, aerobic endosporeforming isolates from Mt Rittmann and Candlemas Island represent a new taxon, which is distinct from 'Bacillus thermoantarcticus' isolated from Mt Melbourne by Nicolaus et al. (1996) and 'Alicyclobacillus acidocaldarius subsp. rittmannii' isolated from $\mathrm{Mt}$ Rittmann (Nicolaus et al., 1998). The description of the new species follows, and Table 3 shows characters that distinguish it from some other thermophilic, aerobic endospore-forming bacteria.

\section{Description of Bacillus fumarioli}

Bacillus fumarioli (fum.a.rio'li. M. L. adj. fumarioli from L. masc. n. fumariolum a smoke vent; whence fumarole, a hole emitting gases in a volcanic area, referring to the habitat from which the organisms were isolated).

Isolated from geothermal soils and active and inactive fumaroles in north Victoria Land, Antarctica, and Candlemas Island, South Sandwich archipelago. Cells are feebly motile, Gram-positive, round-ended rods $(0.5-0.8$ by $4-8 \mu \mathrm{m})$ occurring singly and in pairs and chains on BFA medium at $\mathrm{pH}$ 5.5. On TSA $\mathrm{MnSO}_{4}$ the rods tend to become pleomorphic and then ghost cells after $48-72 \mathrm{~h}$ incubation. Endospores may be formed in small numbers on TSA $\mathrm{MnSO}_{4}$ and in large numbers on BFA medium at $\mathrm{pH} 5 \cdot 5$; they are ellipsoidal to cylindrical, lie paracentrally and subterminally, and do not swell the sporangia (Fig. 5). After 2-3 d on TSA colonies are 5-10 $\mathrm{mm}$ in diameter, low convex, circular and slightly irregular, butyrous, brownish-cream and opaque with a smooth, glossy and sometimes slightly 
iridescent appearance; on BFA medium colonies are 3-8 $\mathrm{mm}$ in diameter, low convex, circular and slightly irregular, with some trailing along streak lines, butyrous, creamy-brown (sometimes darker with age in their centres), and opaque with a smooth, glossy appearance. Minimum temperature for growth lies between 25 and $30^{\circ} \mathrm{C}$, the optimum temperature for growth is $50^{\circ} \mathrm{C}$, and the maximum growth temperature is $55^{\circ} \mathrm{C}$. Minimum $\mathrm{pH}$ for growth lies between $4 \cdot 0$ and $5 \cdot 0$, the optimum $\mathrm{pH}$ for growth is $5 \cdot 5$, and the maximum $\mathrm{pH}$ for growth lies between 6.0 and 6.5 . Organisms are strictly aerobic and catalase-positive. In the API 20E strip, Voges-Proskauer reaction is positive, and gelatin is hydrolysed; reactions for ONPG hydrolysis, arginine dihydrolase, lysine decarboxylase, ornithine decarboxylase, citrate utilization, hydrogen sulphide production, urease, tryptophan deaminase, indole production and nitrate reduction are negative. Hydrolysis of aesculin and of casein negative. Acid without gas is produced from the following carbohydrates: D-fructose, D-glucose, mannitol, D-mannose, $N$-acetylglucosamine (weak), sucrose, trehalose (weak). Acid production from the following carbohydrates is variable: galactose, glycerol, lactose, maltose, D-melibiose, D-melezitose, methyl $\alpha$-D-glucoside, D-raffinose, ribose and D-turanose. Hydrolysis of aesculin is positive. Acid is not produced from the following carbohydrates: adonitol, amygdalin, D- and L-arabinose, D- and L-arabitol, arbutin, cellobiose, dulcitol, erythritol, D- and L-fucose, $\beta$-gentiobiose, gluconate, glycogen, meso-inositol, inulin, 2-keto-Dgluconate, 5-keto-D-gluconate, D-lyxose, methyl $\alpha$-Dmannoside, methyl-xyloside, rhamnose, salicin, sorbitol, L-sorbose, starch, D-tagatose, xylitol, and D- and $\mathrm{L}-x y$ lose. Sensitive to disks of the following antibiotics: ampicillin $(25 \mu \mathrm{g})$, chloramphenicol $(50 \mu \mathrm{g})$, colistin sulphate $(100 \mu \mathrm{g})$, kanamycin $(30 \mu \mathrm{g})$, nitrofurantoin $(50 \mu \mathrm{g})$, streptomycin $(25 \mu \mathrm{g})$ and tetracycline $(100 \mu \mathrm{g})$; resistant to nalidixic acid $(30 \mu \mathrm{g})$.

The major cellular fatty acid is iso- $\mathrm{C}_{15: 0}$, present at a level of about $50 \%$ of the total fatty acids, while iso$\mathrm{C}_{17: 0}$ and anteiso- $\mathrm{C}_{17: 0}$ appear in roughly equal amounts and account for about $30 \%$ of the total fatty acids.

The $\mathrm{G}+\mathrm{C}$ content is $40.7 \mathrm{~mol} \%$ for the type strain, strain LMG 17489 (Rcp Sm1); the 16S rRNA sequence of this strain is deposited at EMBL under accession number AJ250056. In the variable characters listed above, the type strain produces acid without gas from glycerol, maltose, D-melezitose, D-raffinose, D-turanose; and not from galactose, lactose, D-melibiose, methyl $\alpha$-D-glucoside and ribose.

\section{ACKNOWLEDGEMENTS}

N.A.L. is exceptionally grateful to PNRA for the invitation to join the 14th Italian Antarctic Expedition, to Dr D. W.H. Walton and the British Antarctic Survey for enabling him to join that expedition, to R. Bargagli and F. Frati for their kind help during the expedition, and to the Trans-Antarctic
Association (Cambridge; grant no. TAA/98/16) and the Worshipful Company of Scientific Instrument Makers (London) for financial support. We are very grateful to N. J. Russell and P. Convey for collecting soil samples from Mt Rittmann and Candlemas Island. The visit to Cryptogam Ridge, Mt Melbourne, a Specially Protected Area, was covered by Permit no. S12\&13/2/98 from the Foreign and Commonwealth Office, London. N.A.L. thanks Wilma Dodd and Rosemary Rankin for technical support. We are most grateful to bioMérieux sa for providing API materials and for supporting G.F.; P.D.V. and M.H. are indebted to the National Fund for Scientific Research (Belgium) for a position as Research Director and Postdoctoral Research Fellow, respectively. M.H., N.A.L. and P.D.V. are most grateful to the British Council and the Fund for Scientific Research (FSR) for the award of an Academic Research Collaboration Programme travel grant. For personnel and research grants P.D. V. thanks the Onderzoeksfonds RUG (nos 01105893 and 011A1096) and the FSR (no. 3G.0072.96).

\section{REFERENCES}

Armienti, P. \& Tripodo, A. (1991). Petrography and chemistry of lavas and comagmatic xenoliths of Mt Rittmann, a volcano discovered during the IV Italian expedition in northern Victoria Land (Antarctica), Mem Soc Geol It 46, 427-451.

Bargagli, R., Broady, P. A. \& Walton, D. W. H. (1996). Preliminary investigation of the thermal biosystem of Mount Rittmann fumaroles (northern Victoria Land, Antarctica), Antarct Sci 8 , 121-126.

Bonaccorso, A., Maione, M., Pertusati, P. C., Privitera, E. \& Ricci, C. A. (1991). Fumarolic activity at Mount Rittmann volcano (northern Victoria Land, Antarctica), Mem Soc Geol It 46, 453-456.

Broady, P. A. (1993). Soils heated by volcanism. In Antarctic Microbiology, pp. 413-432. Edited by E. I. Friedmann. New York: Wiley-Liss

Broady, P., Given, D., Greenfield, L. \& Thompson, K. (1987). The biota and environment of fumaroles on Mt Melbourne, northern Victoria Land, Polar Biol 7, 97-113.

Bonjour, F. \& Aragno, M. (1984). Bacillus tusciae, a new species of thermoacidophilic, facultatively chemolithotrophic, hydrogen oxidizing sporeformer from a geothermal area, Arch Microbiol 139, 397-401.

Claus, D. \& Berkeley, R. C. W. (1986). Genus Bacillus Cohn 1872. In Bergey's Manual of Systematic Bacteriology, vol. 2, pp. 1105-1139. Edited by P. H. A. Sneath, N. S. Mair, M. E. Sharpe \& J. G. Holt. Baltimore: Williams \& Wilkins.

Coenye, T., Falsen, E., Vancanneyt, M., Hoste, B., Govan, J. R. W., Kersters, K. \& Vandamme, P. (1999). Classification of Alcaligenes faecalis-like isolates from the environment and human clinical samples as Ralstonia gilardii sp. nov, Int J Syst Bacteriol 49, 405-413.

Deinhard, G., Blanz, P., Poralla, K. \& Altan, A. (1987). Bacillus acidoterrestris sp. nov., a new thermotolerant acidophile isolated from different soils, Syst Appl Microbiol 10, 47-53.

De Ley, J., Cattoir, H. \& Reynaerts, A. (1970). The quantitative measurement of DNA hybridization from renaturation rates, Eur J Biochem 12, 133-142.

Ezaki, T., Hashimoto, Y. \& Yabuuchi, E. (1989). Fluorometric deoxyribonucleic acid-deoxyribonucleic acid hybridization in 
microdilution wells as an alternative to membrane filter hybridization in which radioisotopes are used to determine genetic relatedness among bacterial strains, Int J Syst Bacteriol 39, 224-229.

Gordon, R. E., Haynes, W. C. \& Pang, C. H.-N. (1973). The genus Bacillus. Agriculture Handbook no. 427. Washington, DC: US Department of Agriculture.

Harrington, J. H. (1958). Nomenclature of rock units in the Ross Sea region, Antarctica, Nature 182, 290-291.

Heyndrickx, M., Vandemeulebroecke, K., Scheldeman, P., Hoste, B., Kersters, K., De Vos, P., Logan, N. A., Aziz, A. M., Ali, N. \& Berkeley, R. C. W. (1995). Paenibacillus (formerly Bacillus) gordonae (Pichinoty et al. 1986) Ash et al. 1994, is a later subjective synonym of Paenibacillus (formerly Bacillus) validus (Nakamura 1984) Ash et al. 1994: emended description of P. validus, Int J Syst Bacteriol 45, 661-669.

Heyndrickx, M., Vauterin, L., Vandamme, P., Kersters, K. \& De Vos, P. (1996). Applicability of combined amplified 16S rDNA restriction analysis (ARDRA) patterns in bacterial phylogeny and taxonomy, J Microbiol Methods 26, 247-259.

Heyndrickx, H., Lebbe, L., Vancanneyt, M., Kersters, K., De Vos, P., Logan, N. A., Forsyth, G., Nazli, S., Ali, N. \& Berkeley, R. C. W. (1997). A polyphasic reassessment of the Genus Aneurinibacillus, reclassification of Bacillus thermoaerophilus (MeierStauffer et al. 1996) as Aneurinibacillus thermoaerophilus comb. nov., and emended descriptions of $A$. aneurinilyticus corrig., $A$. migulanus, and A. thermoaerophilus, Int J Syst Bacteriol 47, 808-817.

Heyndrickx, M., Lebbe, L., Kersters, K., De Vos, P., Forsyth, G. \& Logan, N. A. (1998). Virgibacillus: a new genus to accommodate Bacillus pantothenticus (Proom and Knight 1950). Emended description of Virgibacillus pantothenticus, Int J Syst Bacteriol 48, 99-106.

Linskens, H. F., Bargagli, R., Cresti, M. \& Forcardi, S. (1993). Entrapment of long-distance transported pollen grains by various moss species in coastal Victoria Land, Antarctica, Polar Biol 13, 81-87.

Llarch, Á., Logan, N. A., Castelví, J., Prieto, M. J. \& Guinea, J. (1997). Isolation and characterization of thermophilic Bacillus spp. from geothermal environments on Deception Island, South Shetland archipelago, Microb Ecol 34, 58-65.

Logan, N. A. \& Berkeley, R. C. W. (1984). Identification of Bacillus strains using the API system, J Gen Microbiol 130, 1871-1882.

Marmur, J. (1961). A procedure for the isolation of deoxyribonucleic acid from micro-organisms, J Mol Biol 3, 109-118.

Mesbah, M., Premachandran, U. \& Whitman, W. B. (1989). Precise measurement of the $\mathrm{G}+\mathrm{C}$ content of deoxyribonucleic acid by high-performance liquid chromatography, Int J Syst Bacteriol 39, 159-167.

Nathan, S. \& Schulte, F. J. (1967). Recent thermal and volcanic activity on Mount Melbourne, northern Victoria Land, Antarctica, $N Z$ J Geol Geophys 10, 422-430.

Nicolaus, B., Lama, L., Esposito, E., Manca, M. C., di Prisco, G. \& Gambacorta, A. (1996). "Bacillus thermoantarcticus" sp. nov. from Mount Melbourne, Antarctica: a novel thermophilic species, Polar Biol 16, 101-104.

Nicolaus, B., Improta, R., Manca, M. C., Lama, L., Esposito, E. \& Gambacorta, A. (1998). Alicyclobacilli from an unexplored geothermal soil in Antarctica: Mount Rittmann, Polar Biol 19, 133-141.

Pearson, W. R. \& Lipman, D. J. (1988). Improved tools for biological sequence comparison, Proc Natl Acad Sci USA 85, 2444-2448.

Pitcher, D. G., Saunders, N. A. \& Owen, R. J. (1989). Rapid extraction of bacterial genomic DNA with guanidium thiocyanate, Lett Appl Microbiol 8, 151-156.

Pot, B., Vandamme, P. \& Kersters, K. (1994). Analysis of electrophoretic whole organism protein fingerprints. In Chemical Methods in Prokaryotic Systematics, pp. 493-521. Edited by M. Goodfellow \& A. G. O'Donnell. Chichester: Wiley.

Schenk, A. \& Aragno, M. (1979). Bacillus schlegelii, a new species of thermophilic, facultatively chemolithoautotrophic bacterium oxidizing molecular hydrogen, J Gen Microbiol 115, 333-341.

Suzuki, Y., Kishigami, T., Inoue, K., Mizoguchi, Y., Eto, N., Takagi, M. \& Abe, S. (1983). Bacillus thermoglucosidasius sp. nov., a new species of obligately thermophilic bacilli, Syst Appl Microbiol 4, 487-495.

Vauterin, L. \& Vauterin, P. (1992). Computer aided objective comparison of electrophoretic patterns for grouping and identification of microoganisms, Eur Microbiol 1, 37-41.

Vauterin, L., Yang, P., Hoste, B., Vancanneyt, M., Civerolo, E. L., Swings, J. \& Kersters, K. (1991). Differentiation of Xanthomonas campestris pv. citri strains by sodium dodecyl sulfate-polyacrylamide gel electrophoresis of proteins, fatty acid analysis, and DNA-DNA hybridization, Int J Syst Bacteriol 41, 535-542.

White, D., Sharp, R. J. \& Priest, F. G. (1993). A polyphasic taxonomic study of thermophilic bacilli from a wide geographical area, Antonie Leeuwenhoek J Microbiol Serol 64, 357-386.

Wynn-Williams, D. D. (1991). Aerobiology and colonization in Antarctica - the BIOTAS programme, Grana 30, 380-393.

Zarilla, K. \& Perry, J. J. (1987). Bacillus thermoleovorans, sp. nov., a species of obligately thermophilic hydrocarbon utilizing endospore-forming bacteria, Syst Appl Microbiol 9, 258-264. 